\title{
THE ASSOCIATION BETWEEN FEEDING PATTERN, INCOME, HOUSEHOLD SAFETY, AND STUNTING EVENTS AMONG FARMER FAMILIES IN GUNUNG LABU COMMUNITY HEALTH CENTER, KERINCI REGENCY, JAMBI
}

\author{
Enda Setiana, Evy Wisudariani, Asparian
}

\section{Universitas Jambi}

\begin{abstract}
Background: Stunting is a condition where the height index according to age is below -2 SD based on World Health Organization standard. Children under five are one of the age groups who are prone to experiencing nutritional problems and diseases. In 2019, the most common nutritional problems for children under five at Gunung Labu Community Health Center were stunting (27.12\%). Nutritional problems in farmers can occur because of the poverty factor which is the root of the nutrition problem. This study was aimed to determine the relationship between household food security, feeding pattern, and household income with the incidence of stunting among children under five.

Subjects and Method: A cross-sectional was conducted at Gunung Labu Community Health Center, Kerinci Regency, Jambi, in February-March 2020. The study subjects were 98 children under five from farmer families. Data were carried out using height measurement and questionnaire. Data analysis was performed using the Chi-Square test.

Results: The prevalence of stunting among children under five was $32.34 \%$. There was a relationship between household food security, feeding pattern, and stunting in children under five, and they were statistically significant. While, household income not related with the incidence of stunting, and it was not statistically significant.

Conclusion: Stunting incidence among children under five is associate with household food security and feeding pattern among farmer families.
\end{abstract}

Keywords: stunting, food security, parenting patterns, farmers

Correspondence:

Evy Wisudariani. Universitas Jambi, Indonesia. Email: evywisudariani@unja.ac.id. Mobile: $+6282377996682$ 